\title{
Two mycoheterotrophic orchids from Thailand tropical dipterocarpacean forests associate with a broad diversity of ectomycorrhizal fungi
}

\author{
Mélanie Roy*1, Santi Watthana ${ }^{2}$, Anna Stier ${ }^{1}$, Franck Richard ${ }^{1}$, \\ Suyanee Vessabutr ${ }^{2}$ and Marc-André Selosse ${ }^{1}$
}

Address: ${ }^{1}$ Centre d'Ecologie Fonctionnelle et Evolutive (CNRS, UMR 5175), Equipe Interactions Biotiques, Montpellier, France and ${ }^{2}$ Queen Sirikit Botanic Garden, Mae Rim, Chiang Mai, Thailand

Email: Mélanie Roy* - melanie.roy@cefe.cnrs.fr; Santi Watthana - s_watthana@yahoo.com; Anna Stier - anna.stier@laposte.net; Franck Richard - franck.richard@cefe.cnrs.fr; Suyanee Vessabutr - vessabutr@yahoo.com; Marc-André Selosse - ma.selosse@wanadoo.fr

* Corresponding author

Published: 14 August 2009

BMC Biology 2009, 7:5 I doi:10.1 186/I74|-7007-7-5 I

This article is available from: http://www.biomedcentral.com/|74|-7007/7/5 I

(c) 2009 Roy et al; licensee BioMed Central Ltd.

This is an Open Access article distributed under the terms of the Creative Commons Attribution License (http://creativecommons.org/licenses/by/2.0), which permits unrestricted use, distribution, and reproduction in any medium, provided the original work is properly cited.

\begin{abstract}
Background: Mycoheterotrophic plants are considered to associate very specifically with fungi. Mycoheterotrophic orchids are mostly associated with ectomycorrhizal fungi in temperate regions, or with saprobes or parasites in tropical regions. Although most mycoheterotrophic orchids occur in the tropics, few studies have been devoted to them, and the main conclusions about their specificity have hitherto been drawn from their association with ectomycorrhizal fungi in temperate regions.
\end{abstract}

Results: We investigated three Asiatic Neottieae species from ectomycorrhizal forests in Thailand. We found that all were associated with ectomycorrhizal fungi, such as Thelephoraceae, Russulaceae and Sebacinales. Based on ${ }^{13} \mathrm{C}$ enrichment of their biomass, they probably received their organic carbon from these fungi, as do mycoheterotrophic Neottieae from temperate regions. Moreover, ${ }^{13} \mathrm{C}$ enrichment suggested that some nearby green orchids received part of their carbon from fungi too. Nevertheless, two of the three orchids presented a unique feature for mycoheterotrophic plants: they were not specifically associated with a narrow clade of fungi. Some orchid individuals were even associated with up to nine different fungi.

Conclusion: Our results demonstrate that some green and mycoheterotrophic orchids in tropical regions can receive carbon from ectomycorrhizal fungi, and thus from trees. Our results reveal the absence of specificity in two mycoheterotrophic orchid-fungus associations in tropical regions, in contrast to most previous studies of mycoheterotrophic plants, which have been mainly focused on temperate orchids.

\section{Background}

During the last decade, important advances have been made in our understanding of nutrition of achlorophyllous, heterotrophic plants [1]. Beyond the classical plant- parasitic taxa, a strategy called mycoheterotrophy (MH) has been shown in more than 400 species within several plant clades, showing patterns of convergent evolution to heterotrophy [2]. MH plants receive carbon from soil 
fungi colonising their roots, forming the so-called mycorrhizal symbiosis [3]. $\mathrm{MH}$ in adult (above-ground) life phases has evolved repetitively among orchids [4]. Recent advances were made in identifying mycorrhizal fungi of MH plants by molecular methods, thus revealing their ultimate carbon source, the photosynthesised carbon of autotrophic plants associated with the same mycorrhizal fungi in most cases.

PCR amplification and sequencing of the fungal ribosomal DNA from mycorrhizae allowed identification of MH mycorrhizal fungi in more than a dozen MH orchid species [5-9], as well as in several MH species among Ericaceae [10], Gentianaceae and Corsiaceae [11], and Burmanniaceae [12]. All these studies identified a very specific association, that is, of each MH species with fungi from a single genus or even a sub-clade within a genus. Most fungi involved are mycorrhizal partners on other autotrophic plants, forming arbuscular mycorrhizae (AM) [11-13]. As exceptions, some tropical orchids associate with saprobic fungi [14-17], but are often specific too. Aside from these tropical exceptions, the fungal associates of most MH plants suggest that a carbon flow from surrounding autotrophic plants to the MH plants, via the shared mycorrhizal fungus, is likely to occur.

For temperate $\mathrm{MH}$ plants, the stable isotope composition of $\mathrm{MH}$ plants supports nutrition on ectomycorrhizal (ECM) fungi. Natural abundances in ${ }^{13} \mathrm{C}$ and ${ }^{15} \mathrm{~N}$ are major tools in ecology to detect the food source of an organism $[18,19]$. Most organisms have a ${ }^{13} \mathrm{C}$ abundance similar to their food source, and indeed $\mathrm{MH}$ plants have similar or slightly higher ${ }^{13} \mathrm{C}$ abundances than associated fungi $[20,21]$. As an exception, however, ECM fungi are richer in ${ }^{13} \mathrm{C}$ than autotrophic plants [22]. Although the reasons for this fractionation are unclear [23], it entails a difference in ${ }^{13} \mathrm{C}$ abundance between autotrophic and MH plants [24]. ${ }^{15} \mathrm{~N}$ accumulates along food chains, due to a fractionation at each trophic level [19], and its abundance usually increases in the order autotrophic plants < ECM fungi $\leq \mathrm{MH}$ plants $[20,24]$. Moreover, ${ }^{14} \mathrm{C}$ labelling experiments have provided direct evidence that $\mathrm{MH}$ orchid and Ericaceae receive assimilates from surrounding trees through shared mycorrhizal fungi $[25,26]$.

Current investigations are strongly biased toward $\mathrm{MH}$ plants from temperate regions. For example, with the exception of a recent study $[16,17]$, few $\mathrm{N}$ and $\mathrm{C}$ isotopic analyses have been performed on tropical MH plants. The locations of the laboratories involved, and perhaps the Convention on International Trade in Endangered Species of Wild Fauna and Flora [27], may have limited research on MH species in tropical regions. However, dense cover in tropical forests, which select for light-independent nutrition, provides a useful opportunity to study $\mathrm{MH}$ plants. Indeed, among the $c a$. $200 \mathrm{MH}$ orchids, more than
$90 \%$ occur in tropical regions, including a diversity hot spot in tropical Asia where 120 species grow $[4,28]$. There have been recent investigations on mycorrhizae from tropical orchids, but they exclusively focused on green, epiphytic species (see, for example, [29,30]). They revealed more or less specific associations with the fungal clades found in autotrophic temperate orchids, the 'rhizoctonias' [31]. This group of otherwise parasitic and saprobic fungi encompasses Ceratobasidiales, Tulasnellales and Sebacinales (from clade B sensu Weiss et al. [32]), and is absent from $\mathrm{MH}$ species

Our aim was to investigate the identity of the fungal partners and specificity of the association of tropical Asiatic $\mathrm{MH}$ orchids, and to compare the putative origin of their carbon with that of temperate MH orchids. In this study, two important factors were taken into account. First, ECM fungi are absent from some tropical forests [3]. We thus focused on tropical Asiatic forests that are dominated by ECM Fagaceae and Dipterocarpaceae tree species $[3,33]$. Here, as in temperate forests, AM, ECM, and various saprobic fungi are available, as well as rhizoctonias associated with green orchids [34]. Second, we focused on MH species from a clade already studied in temperate regions to control for differences resulting from the orchids' phylogenetic position. The Neottieae, in which MH species arose several times [35,36], are well studied in temperate regions, where they reveal specific associations with ECM fungal clades: Thelephoraceae in Cephalanthera austinae [37], Russulaceae in Limodorum abortivum [38], and Sebacinales in Neottia nidus-avis [25,39].

The tropical Asiatic Neottieae tribe encompasses $33 \mathrm{MH}$ species from the enigmatic genus Aphyllorchis [35], and thus represents one of the most diversified $\mathrm{MH}$ genera. The position of Aphyllorchis among the Neottieae is still not supported by molecular data [35], and even its monophyly is questioned [40]. In this study, we focused on three MH species occurring in ECM forests from Thailand, namely Aphyllorchis montana, A. caudata and Cephalanthera exigua (Figure 1). Assuming phylogenetic conservatism for the traits under study, and based on temperate species already investigated, we expected them to be specifically associated with narrow ECM clades, and to use tree photosynthates by way of shared ECM fungi. Our aims were, within Thailand forests and for these three species, to test these predictions, that is, (i) to confirm that Aphyllorchis belongs to Neottieae; (ii) to identify fungal associates of the three species; (iii) to infer their fungal specificity level; and (iv) to investigate their isotopic content in ${ }^{13} \mathrm{C}$ and ${ }^{15} \mathrm{~N}$, to infer their carbon source.

\section{Results}

Phylogenetic position of Aphyllorchis spp. and C. exigua Based on three markers (ITS, trnS-G and $r b c L$; GB accession numbers FI454868-FJ454884, Additional file 1), the 


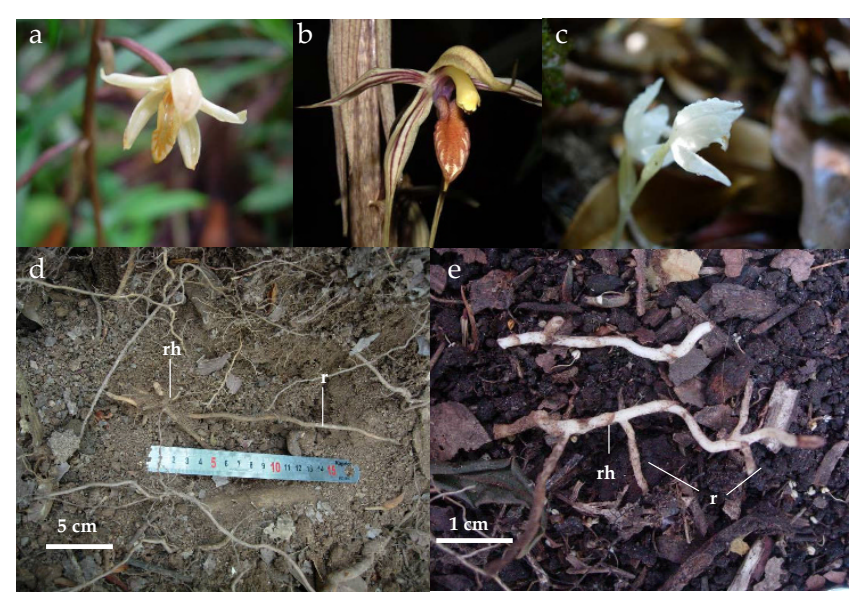

Figure I

The three mycoheterotrophic orchid species. The three mycoheterotrophic orchid species under study, A. montana (a), A. caudata (b), and C. exigua (c), with closer views of the underground parts of $A$. montana roots (d) and $C$. exigua (e). Abbreviations: r, root; rh, rhizome.

Neottieae tribe was monophyletic and included the two Aphyllorchis under study (Figure 2). Thaia saprophytica, a green species from Thailand, had a basal position, but two markers ( $r b c L$ and $t r n S-G$ ) were not obtained for this species and this limited the support level. Identical topologies at genus level were found, although with lower support levels, when using the three markers separately (data not shown). The genera Epipactis, Listera and Cephalanthera were monophyletic, but this, together with their relative positions, remained weakly supported. The position of C. exigua within the genus Cephalanthera was well supported, and the two Aphyllorchis species clustered together as a well-supported sister clade to the European genus Limodorum.

\section{Molecular identification of root fungi}

Forty A. montana individuals (from seven populations, that is, 288 root samples; Table 1[41] and Additional file 2) produced 220 simple PCR products, representing 135 restriction fragment length polymorphism (RFLP) types, 104 of which were successfully sequenced. In addition, we successfully cloned eight multiple PCR products that produced 11 different sequences (Additional file 2). BLAST identifications showed that $83 \%$ were putatively from ECM fungi, $4 \%$ from rhizoctonias, 3\% from endophytes and $10 \%$ from saprobic fungi (Figure $3 \mathrm{a}$ and $3 \mathrm{~d}$; Additional file 2). ECM fungi belonged to diverse taxa, mainly Russulaceae, Thelephoraceae and Clavulinaceae. Endophytic fungi and Thanatephorus sp., a typical orchid mycorrhizal fungus, were found each from a single sample, on individuals also displaying ECM fungi. Thirteen different saprobes were identified, each occurring only on a single sample, except Resinicium sp. and Malassezia sp. (two samples each). Saprobes were mainly basidiomycetes (69\%) and ascomycetes (23\%). In all, $15 \%$ of orchid individuals did not reveal any ECM fungus, $45 \%$ of the individuals revealed a single ECM sequence (sometimes in addition to saprobes and endophytes), and all remaining individuals associated with two to four ECM fungi (Figure 4), sometimes on the same root (Figure 5). Thus, orchid individuals had diverse partners (up to nine putative ECM species from five different genera in a single individual AMD7.1, Additional file 2, Figure 5). In seven samples, two different sequences were detected by cloning. In five individuals (12.5\%) only, identical fungal sequences were retrieved from different roots.

Nine A. caudata individuals (from two populations, that is, 27 samples; Table 1 and Additional file 2) produced 23 simple PCR products that belonged to 12 RFLP types, nine of which were successfully sequenced (Additional file 2). Four multiple PCR products were cloned and produced eight different sequences (Additional file 2). Apart from an endophyte, found only once (Hypocrea sp.; Figure 3b and 3d), all sequences were putatively ECM, and mainly belonged to Russulaceae, Thelephoraceae and Sebacinales (from the ECM-forming clade A, sensu Weiss et al. [32]). Among all individuals, 55\% displayed a single ECM fungus, whereas $45 \%$ displayed two to three ECM fungi. As for A. montana, no fungal taxon was shared by all individuals.

Nine C. exigua individuals (72 samples) from one population produced 63 simple PCR products belonging to 16 RFLP types that were all sequenced. Putative ECM fungi dominated the fungal community (84\%), with some rhizoctonias (5\%) and saprobes (11\%; Figure $3 \mathrm{c}$ and $3 \mathrm{~d}$ ). Thelephoraceae represented $65 \%$ of identified fungi, and one (FJ454907) was even found in 16 samples arising from seven individuals. Putative ECM Helotiales and Naucoria sp. were found in one sample each, as well as saprobes including Trichoderma sp. (8\% of all fungi) and other ascomycetes (in one sample each). In all, six out of nine individuals exclusively associated with Thelephoraceae, two displayed two different ECM fungi, with a dominance of Thelephoraceae ( $+80 \%$ of the samples), and one displayed only Helotiales. Thus, Thelephoraceae were the preferred fungal associates of $C$. exigua.

\section{Molecular identification of A. montana fungal pelotons}

The identity of fungi colonising mycorrhizal cells was assessed on peloton pools (pools of twelve pelotons from a single root section) from two A. montana individuals at Doi Suthep \#2 (Table 1 and Additional file 2). On AMD6.1, two pools revealed a Helotiales (FI454973) already found on the same individual, and four revealed a Russulaceae (FJ454956) already found on other Doi 


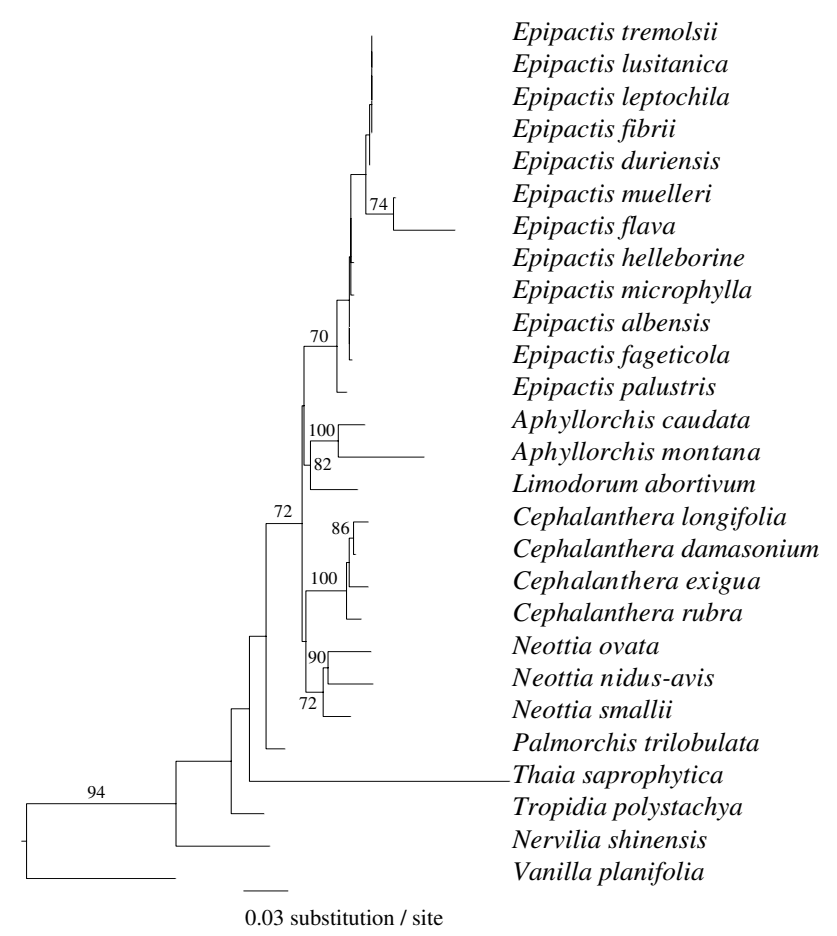

Figure 2

Phylogenetic tree of the Neottieae tribe. Phylogenetic tree of the Neottieae tribe showing positions of A. montana, $A$. caudata and $C$. exigua; Mycoheterotroph species are in bold. Phylogeny based on a concatenation of ITS, trnS-G and $r b c L$, using the maximum likelihood method (general time reversible model). Numbers on branches indicate bootstrap values above $70 \%$ (over I,000 replicates).

Suthep \#2 individuals (Additional file 2). On AMD7.1, two fungi already found on the same individual were recovered, namely a Clavulinaceae (FJ454977; three pools) and a Thelephoracae (FJ454979; one pool), while cloning on another pool revealed a mix of the two previous fungi and a Russulaceae (FI623066, close to R. illota and some Russulaceae already found at Doi Suthep \#2, Additional file 2). On both individuals, four pools did not amplify. These data corroborated that (i) several ECM fungi were mycorrhizal on the same individual, even the same root, and (ii) ECM asco- and basidiomycetes were mycorrhizal on A. montana.

\section{Analysis of the fungal community analysis}

Russulaceae, by far the most represented on A. montana and A. caudata (39.8\% of the sequence found, in $33.6 \%$ of typed samples), were phylogenetically over-dispersed (Figure 6), further supporting the low specificity of mycorrhizal association. Even fungi identified from the same individual did not cluster together (data not shown), and different Russulaceae species sometimes colonised the same root (Figure 5). Considerable internal transcribed spacer (ITS) variations in Thelephoraceae (also very frequent, $30.0 \%$ of the sequence found on Aphyllorchis spp. and $63.2 \%$ on C. exigua) forbade phylogenetic analysis, but sequences were not more similar within than between orchid species (data not shown).

Using a threshold of $<97 \%$ of ITS variation to delineate species, 112 species were recorded in A. montana, 23 in A. caudata and 31 in C. exigua. In all, $94 \%$ of these species were represented by a single sequence. Only four species occurred on more than one individual, and were all from the same A. montana population (Additional file 2). Rarefaction analyses provide similar trends when (i) considering either all fungi or ECM fungi only; (ii) making the analysis at fungal family or species level; and (iii) pooling all populations or separating them to calculate mean values for each species. In every case, curves for A. montana and $A$. caudata were similar (Figure 7a), and higher than for $C$. exigua, so that the low fungal diversity in this species was not a sampling artefact. In detrended component analysis (DCA), no differences in ECM fungal community were found between A. montana populations (data not shown) or between the two Aphyllorchis species (Figure $7 \mathrm{~b})$. In contrast, the C. exigua ECM fungal community differed from two Aphyllorchis species $(P<0.01$ for both tests; Figure $7 \mathrm{~b})$. Neither the forest type nor the geographical origin had a significant effect ( $P>0.05$; data not shown). Results were unchanged when considering all fungi. Thus, C. exigua strongly differed in fungal community structure from the two Aphyllorchis species, both quantitatively and qualitatively.

\section{Stable isotope analyses}

We tested by analyses of natural content in stable isotopes and $\mathrm{C} / \mathrm{N}$ ratio whether $\mathrm{ECM}$ fungi were potential $\mathrm{C}$ sources for the MH orchids. At Doi Suthep \#2 (Figure 8a), significant differences for both $\delta^{13} \mathrm{C}$ and $\delta^{15} \mathrm{~N}$ occurred in the order autotrophic Boesenbergia rotunda < other autotrophic plants $<A$. montana $\leq$ ECM fungi (including taxa found on A. montana roots, Russulaceae and Thelephoraceae). $\mathrm{C} / \mathrm{N}$ ratio values were higher for autotrophs than for fungi $(12.1 \pm 1.2-$ mean $\pm \mathrm{SD})$ and A. montana $(11.9 \pm 1.2$; Figure 9a): the latter two were not significantly different (Mann-Whitney test, $P=0.81$ ), but significantly lower than autotrophs $(22.6 \pm 3.0$ on average, $P<$ $0.001 ; B$. rotunda did not differ from other autotrophs in this respect; Figure 9a). $\delta^{13} \mathrm{C}$ values and variations in $\delta^{15} \mathrm{~N}$ and $\mathrm{C} / \mathrm{N}$ ratio were congruent with a food chain from autotrophs to ECM fungi and $A$. montana.

At Doi Suthep \#3, $\delta^{13} \mathrm{C}$ was higher for A. caudata than for autotrophic plants but (not significantly) lower than for saprobic fungi. A. caudata had $\delta^{15} \mathrm{~N}$ intermediate between the different saprobic fungal species, but higher than autotrophs (among them, the orchid Ludisia discolor had 
Table I: Description and location of sampling sites.

\begin{tabular}{|c|c|c|c|}
\hline Species and sampling site & Geocodes and elevation & Type of forest and dominant trees $\alpha$ & No. of orchids sampled \\
\hline \multicolumn{4}{|l|}{ Aphyllorchis montana } \\
\hline Doi Suthep \#I & $\begin{array}{l}18^{\circ} 48^{\prime} 39^{\prime \prime} \mathrm{N} \\
98^{\circ} 55^{\prime} 00^{\prime \prime} \mathrm{E} \\
1053 \mathrm{~m}\end{array}$ & $\begin{array}{l}\text { Evergreen forest: Castanopsis acuminatissima (F), } \\
\text { Castanopsis diversifolia (F), Dipterocarpus costatus (D), } \\
\text { Manglietia garretti (Magnoliaceae), Carallia brachiata } \\
\text { (Rhizophoraceae). }\end{array}$ & 11 \\
\hline Doi Suthep \#2 & $\begin{array}{l}18^{\circ} 48^{\prime} 24^{\prime \prime} \mathrm{N} \\
98^{\circ} 55^{\prime} 19^{\prime \prime} \mathrm{E} \\
950 \mathrm{~m}\end{array}$ & $\begin{array}{l}\text { Evergreen forest: Dipterocarpus costatus (D), Castanopsis } \\
\text { diversifolia (F). }\end{array}$ & $\begin{array}{l}\text { II } \\
(+ \text { isotopes samples })^{\beta}\end{array}$ \\
\hline Queen Sirikit Botanical Garden \#I & $\begin{array}{l}18^{\circ} 54^{\prime} 24^{\prime \prime} \mathrm{N} \\
98^{\circ} 5 I^{\prime} 48^{\prime \prime} \mathrm{E} \\
811 \mathrm{~m}\end{array}$ & $\begin{array}{l}\text { Dry dipterocarpacean forest: Dipterocarpus costatus (D), } \\
\text { Shorea roxburghii (D), Castanopsis argyrophylla (F), } \\
\text { Castanopsis tribuloides (F), Lithocarpus thomsonii (F), } \\
\text { Diospyros variegate (Ebenaceae), Phoebe lanceolata } \\
\text { (Lauraceae), Protium serratum (Burseraceae). }\end{array}$ & 8 \\
\hline Queen Sirikit Botanical Garden \#2 & $\begin{array}{l}18^{\circ} 53^{\prime} 36^{\prime \prime} \mathrm{N} \\
98^{\circ} 51 ' 27^{\prime \prime} \mathrm{E} \\
729 \mathrm{~m}\end{array}$ & $\begin{array}{l}\text { Oak forest: Lithocarpus sootepensis (F), Dipterocarpus } \\
\text { costatus (D), Shorea roxburghii (D). }\end{array}$ & 2 \\
\hline Nam Nao & $\begin{array}{l}16^{\circ} 93^{\prime} 48^{\prime \prime} \mathrm{N} \\
101^{\circ} 33^{\prime} 39^{\prime \prime} \mathrm{E} \\
700 \mathrm{~m}\end{array}$ & $\begin{array}{l}\text { Bamboo forest: Castanopsis diversifolia (F), Lithocarpus sp } \\
\text { (F). }\end{array}$ & 1 \\
\hline Khao Chamao & $\begin{array}{l}12^{\circ} 58^{\prime} 4 I^{\prime \prime ~ N ~} \\
101^{\circ} 42^{\prime} 05^{\prime \prime} \mathrm{E} \\
800 \mathrm{~m}\end{array}$ & Dipterocarpacean forest: Dipterocarpus dyeri (D). & 4 \\
\hline Klong Pla Kaeng & $\begin{array}{l}12^{\circ} 56^{\prime} 08^{\prime \prime} \mathrm{N} \\
101^{\circ} 44^{\prime} 09^{\prime \prime} \mathrm{E} \\
700 \mathrm{~m}\end{array}$ & Dipterocarpacean forest: Dipterocarpus dyeri (D). & 2 \\
\hline \multicolumn{4}{|l|}{ Aphyllorchis caudata } \\
\hline Doi Suthep \#3 & $\begin{array}{l}18^{\circ} 48^{\prime} 39^{\prime \prime} \mathrm{N} \\
98^{\circ} 55^{\prime} 00^{\prime \prime} \mathrm{E} \\
1050 \mathrm{~m}\end{array}$ & $\begin{array}{l}\text { Evergreen forest: Dipterocarpus costatus (D), Castanopsis } \\
\text { diversifolia (F). }\end{array}$ & $\begin{array}{l}\text { II } \\
(+ \text { isotopes samples })^{\beta}\end{array}$ \\
\hline Doi Inthanon & $\begin{array}{l}18^{\circ} 35^{\prime} 25^{\prime \prime} \mathrm{N} \\
98^{\circ} 29^{\prime} 09^{\prime \prime} \mathrm{E} \\
1000 \mathrm{~m}\end{array}$ & $\begin{array}{l}\text { Evergreen forest: Castanopsis acuminatissima (F), } \\
\text { Lithocarpus sp. (F), Quercus sp. (F), Schima wallichii } \\
\text { (Theaceae). }\end{array}$ & 2 \\
\hline \multicolumn{4}{|l|}{ Cephalanthera exigua } \\
\hline Doi Pee Pan Nam & $\begin{array}{l}19^{\circ} 06^{\prime} 05^{\prime \prime} \mathrm{N} \\
99^{\circ} 20^{\circ} 84^{\prime \prime} \mathrm{E} \\
2015 \mathrm{~m}\end{array}$ & $\begin{array}{l}\text { Evergreen forest: Castanopsis acuminatissima (F), } \\
\text { Castanopsis sp. (F), Gironniera sp. (Ulmaceae), Lithocarpus } \\
\text { sp. (F), Michelia floribunda (Magnoliaceae), Myrica esculenta } \\
\text { (Myricaceae), Neolitsea sp. (Lauraceae), Camellia oleifera } \\
\text { (Theaceae), Schima wallishii (Theaceae), Syzygium angkae, } \\
\text { Syzygium sp. (Myrtaceae). }\end{array}$ & $\begin{array}{l}9 \\
(+ \text { isotopes samples })^{\beta}\end{array}$ \\
\hline
\end{tabular}

$\alpha$ F: Fagaceae; D: Dipterocarpaceae.

$\beta$ For species sampled for isotopic studies, see Figure 6.

significantly higher $\delta^{15} \mathrm{~N}$ ). Unfortunately, no ECM fungi were found, but since they are expected to have lower $\delta^{13} \mathrm{C}$ and higher $\delta^{15} \mathrm{~N}$ than saprobes [22], they may well be the orchid's $\mathrm{C}$ and $\mathrm{N}$ source. Most samples had similar $\mathrm{C} / \mathrm{N}$ ratio values (Figure $9 \mathrm{~b})$. The $A$. caudata ratio $(15.5 \pm 2.2)$ did not significantly differ from that of saprobic fungi $(15.4 \pm 6.9$ on average, $P=0.65)$ and was (not significantly) higher than that of autotrophs $(18.9 \pm 3.2$ on average, $P=0.38$ ). These results did not reject the hypothesis of a food chain from autotrophs to ECM fungi and A. caudata.

At Doi Pee Pan Nam, significant differences for $\delta^{13} \mathrm{C}$ occurred in the order autotrophic non-orchid plants <
ECM fungi plus the orchids Cheirostylis montana $<$ C. exigua (Figure 8c). C. exigua and the fungal species had significantly higher $\delta^{15} \mathrm{~N}$ than all autotrophic non-orchid plants, and Cheirostylis montana showed an intermediate (significantly different) value between these two groups. C. exigua $\mathrm{C} / \mathrm{N}$ ratio $(9.8 \pm 0.9)$ did not differ from that of Cheirostylis montana $(8.3 \pm 0.3)$ and one ECM fungal species (Laccaria laccata, $P=0.08$; Figure $8 \mathrm{c}$ ), but these values were significantly lower than for other ECM fungi $(11.66 \pm 1.23, P=$ 0.01 ), which, in turn, had a significantly lower $\mathrm{C} / \mathrm{N}$ ratio than non-orchid autotrophic plants $(22.2 \pm 1.5, P=$ 0.002). These results suggested that (i) C. exigua could receive $\mathrm{C}$ and $\mathrm{N}$ from ECM fungi, and also that (ii) Cheirostylis montana may receive part of its $\mathrm{C}$ from fungi. 

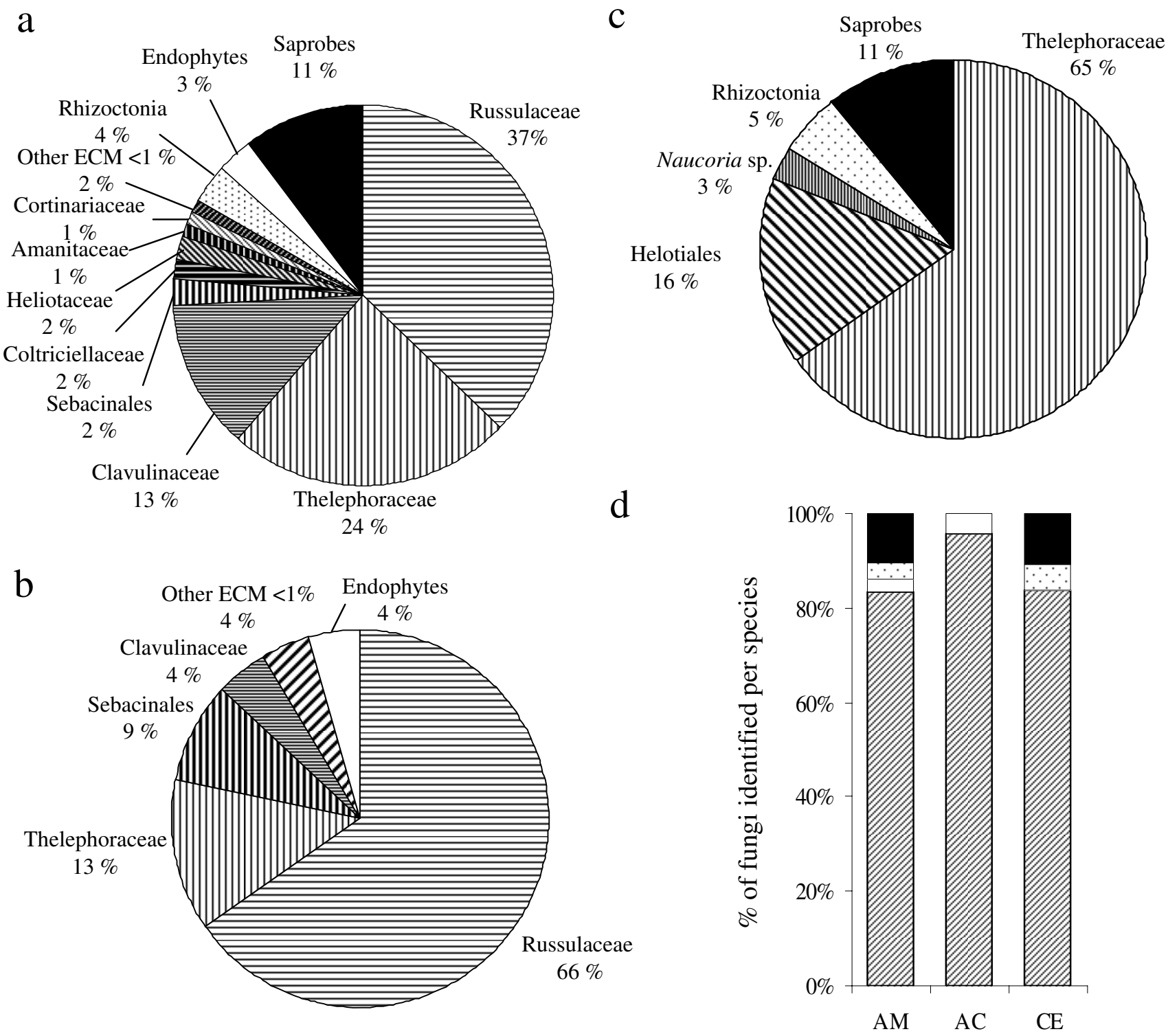

\section{Figure 3}

Description of the community of fungi identified in the three mycoheterotrophic species roots. Frequency of occurrence of fungal taxa identified in each investigated orchid species grouped on a family/order basis for $A$. montana (a), $A$. caudata (b), and C. exigua (c), or grouped by ecology ((d) AM: A. montana; AC: A. caudata; CE: C. exigua; ectomycorrhizal taxa are represented by black lines, rhizoctonias by white dots on black background, endophytes by black dots on white background, and saprophytes in white).

\section{Discussion}

We show for the first time that (i) at least some Aphyllorchis belong to the Neottieae tribe; (ii) tropical (Thailand) Neottieae associate with ECM fungi; and (iii) that they are likely to use their ECM fungi (and thus nearby trees) as a $\mathrm{C}$ source. This is congruent with what is known from temperate Neottieae species $[5,20,21,37]$, but we provide here the first isotopic evidence that tropical $\mathrm{MH}$ orchids associate with ECM fungi. Furthermore, in sharp contrast to the high specificity hitherto found in all investigated $\mathrm{MH}$ species [1], and especially MH orchids [9], mycorrhizal associations in the two Aphyllorchis species studied here revealed a very low specificity, while $C$. exigua proved to be more specific.

\section{Tropical MH Neottieae associate with ECM fungi}

In temperate regions, ECM fungi consistently associate with roots of Neottieae, both green [36,41-44] and $\mathrm{MH}$ 


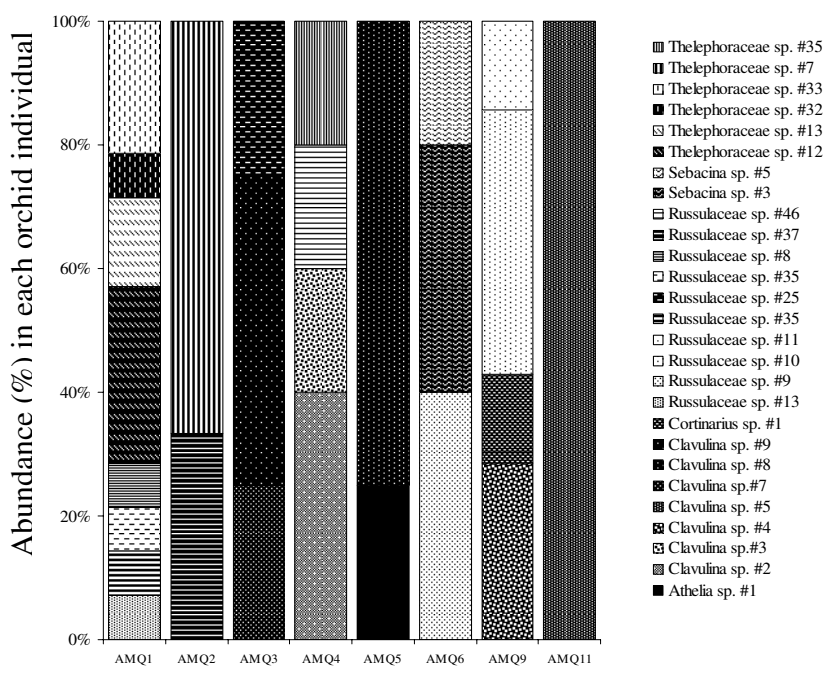

Figure 4

Differences in ectomycorrhizal taxa between orchid individuals from a given population. Diversity and abundance of ectomycorrhizal taxa identified in 10 individuals (AMQI to I0) from an A. montana population (Queen Sirikit Botanical Garden \#I).

$[5,25,37,39]$. Here, we found that most root fungi had a putative ECM ecology. Although endophytes, saprobes and some rhizoctonias were also found, peloton analysis in A. montana only recovered ECM fungi. The mycorrhizal status of putative endophytes and saprobes remains questionable, as in previous studies on Cephalanthera spp. $[36,41]$. ECM fungi are common in Dipterocarpaceae and/or Fagaceae forests of South-East Asia [45,46], and especially of Thailand [47]. The most frequent taxa in this study (Russulaceae, Thelephoraceae) are also the most abundant under Dipterocarpaceae [45,47], where Clavulinaceae and Sebacinales clade A are also known [48]. While temperate Neottieae often associate with taxa forming hypogeous fruit bodies (such as Tuber or Hymenogaster; [49]), little evidence for this trend was found here (with the possible exception of sequence FJ454490 on $C$. exigua, closely related to the hypogeous Arcangeliella, Figure 6). Relatively wet conditions in the investigated forests may explain this, since hypogeous taxa have been shown to be adapted to dry environments [3]. Yet, hypogeous taxa such as Sclerodermataceae exist in Thailand [47]. Moreover, the absence of hypogeous taxa remains difficult to confirm (i) from sequencing data only, and (ii) in a context where the fungal diversity remains poorly explored.

A. montana and A. caudata harboured a highly diverse ECM community (Additional file 2, Figure 5, Figure 6), very similar for the two species (Figure 6, Figure 7b), dominated by Russulaceae and Thelephoraceae, the latter also dominating on C. exigua. Russulaceae are specific associates of the Mediterranean Limodorum abortivum [38], a sister species to the genus Aphyllorchis (Figure 2); however, the species found here were unrelated to the $R$. delica clade mycorrhizal on L. abortivum (Figure 7). C. exigua specifically associated with Thelephoraceae, which are specific associates of the related North American MH C. austiniae and colonise, although not exclusively, green European and Asiatic Cephalanthera spp. [38,41,42,44,50]. The existence of some phylogenetic inertia in fungal preference within Neottieae (or even within the genus Cephalanthera) is an appealing possibility that deserves further study, including more species and a more robust phylogeny of this tribe. With the possible reversion of some Epipactis sp. $[36,42]$, we confirm here that the Neottieae lost association with the rhizoctonias (the plesiomorphic mycorrhizal feature among orchids) and became associated with ECM fungi irrespective of their global localisation (a Cephalanthera longifolia individual from a Myanmar forest also revealed ECM fungi, including Russulaceae - GB accession numbers FJ454917-FJ454919, see Figure 6).

Tropical MH orchids offer considerable diversity in ecology of associated fungi. ECM fungi have already been found in some tropical MH orchids, such as Lyophyllum shimeji (in Erythrorchis ochobiensis [51]) or ECM Ceratobasidiaceae (in Chamaegastrodia sikokiana [52]). Most species associate with non-ECM fungi, that is, parasites [53] or saprobes [14-17,54,55], a fungal ecology never found in temperate $\mathrm{MH}$ orchids. This fungal diversity is reflected in the fact the MH Gastrodia nana and Epipogium roseum, both mycorrhizal with saprobic fungi $[14,16,17]$, also occur in the Thailand forests where this study was carried out (Watthana and Roy, personal observations). In this framework, it is tempting to speculate that other factors, such as contingency or phylogenetic inertia, contribute to the ecology of the fungus in tropical orchids. For Neottieae, the previously mentioned shift from rhizoctonias to ECM fungi $[36,42]$ allowed diversification in ECM forests, not only in temperate regions where such forest dominates, but also in tropical forest harbouring ECM trees. The analysis of mycorrhizal partners in the few Neottieae occurring in tropical America and Africa, as well as in some of the other 33 Aphyllorchis species in tropical Asia [35], is now pending, to allow the construction of a global phylogeographic scenario for the Neottieae.

\section{Tropical MH Neottieae likely receive $C$ from nearby $E C M$ trees}

Since ECM fungi almost exclusively receive $\mathrm{C}$ from host trees [3], the investigated $\mathrm{MH}$ species may indirectly exploit the nearby trees, by way of mycelial links. This was described for temperate species $[5,39,56]$, and corroborated by the high, fungal-like ${ }^{13} \mathrm{C}$ and ${ }^{15} \mathrm{~N}$ in $\mathrm{MH}$ plants $[20,24]$. Here, our isotopic analyses show similar patterns, 
a
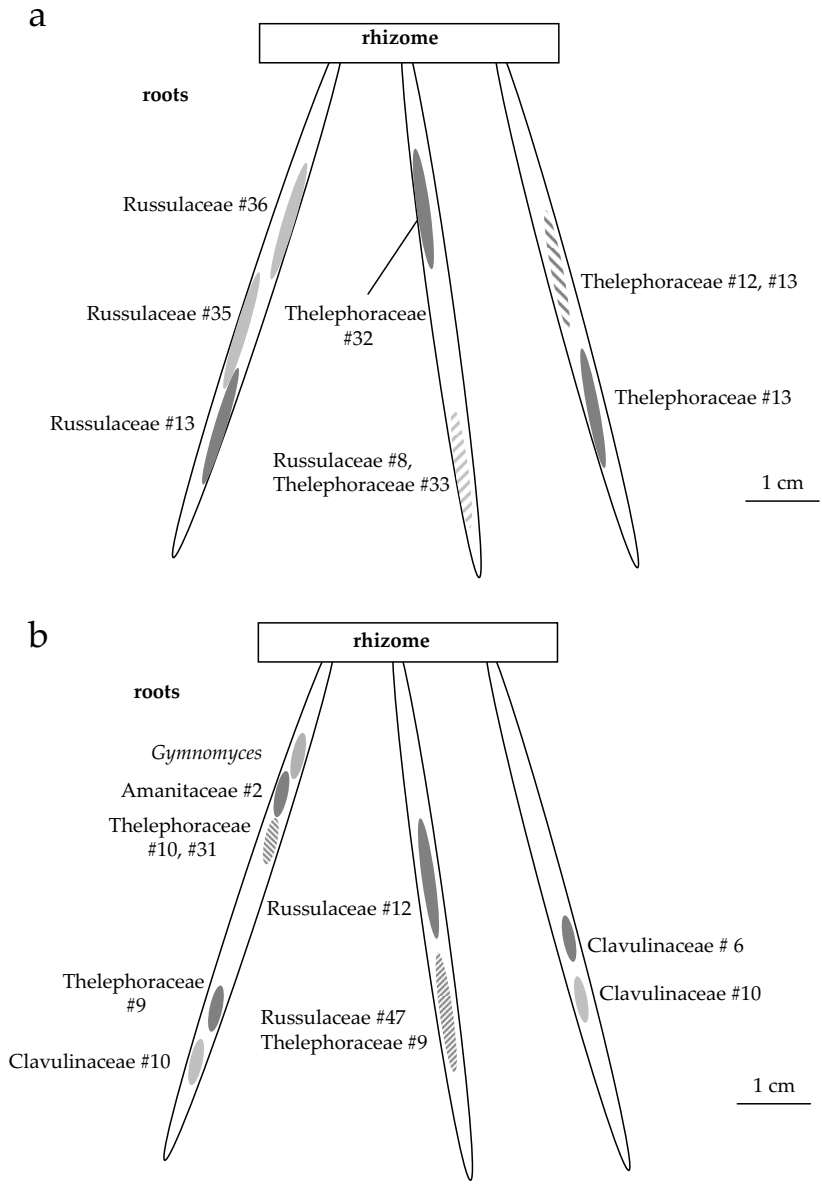

Figure 5

Distribution of identified fungi on the root system of A. montana. Diagram of fungal colonisation on two A. montana root systems, on QI (a) and on D7.I (b). Numbers correspond to putative species identified (see Additional file 2 ). Slashed areas display two different fungi, identified on the same I to $2 \mathrm{~mm}$-thick root section.

congruent with $\mathrm{C}$ transfer from trees to $\mathrm{MH}$ species, via ECM fungi, for tropical sites.

As in temperate ecosystems, $\delta^{13} \mathrm{C}$ were higher for fungi than for autotrophs [57]; unfortunately, the sampling did not allow comparison between saprobic and ECM fungi on each site. Values of $\delta^{13} \mathrm{C}$ tended to be equal or higher for $\mathrm{MH}$ orchids as compared with ECM fungi at Doi Suthep \#2 (-25.1\%o vs -27.6\%o) and Doi Pee Pan Nam ($23.1 \%$ vs $-26.2 \%$ ). At Doi Suthep \#3, where no ECM fungi were available, saprobic fungi were higher in $\delta^{13} \mathrm{C}$. Since saprobes usually tend to have higher $\delta^{13} \mathrm{C}$ than ECM fungi $[22,57]$, this site may not contradict the common trend at the two others. Although it is often assumed that $\delta^{13} \mathrm{C}$ are identical in ECM fungi and $\mathrm{MH}$ plants [20], some ECM fungi from the same site can be 1 to $2 \%$ lower in $\delta^{13} \mathrm{C}$ than $\mathrm{MH}$ plants [21]. Whether the differences observed here are specific to these tropical models or the result of ECM sampling unrepresentative of the mycorrhizal species is an open question. However, the difference in $\delta^{13} \mathrm{C}$ between $\mathrm{MH}$ and autotrophic plants (ranging from $6.8 \%$ o to $9.9 \%$ ) was in the range observed in temperate ecosystems $(+6.9 \pm 1.5 \%$ [24]), whereas more diverse values were found for $\mathrm{MH}$ orchids associated with saprobic fungi (up to $+12 \%$ o $[16,17]$ ).

Investigated $\mathrm{MH}$ orchids tended to have higher $\delta^{15} \mathrm{~N}$ and equal to lower $\mathrm{C} / \mathrm{N}$ ratio values than ECM fungi, as expected between two consecutive levels in a food chain, respectively due to isotopic fractionation for ${ }^{15} \mathrm{~N}[18,20]$ and the loss of respiratory $\mathrm{C}$ [41]. In all, the isotopic data are congruent with a $\mathrm{C}$ flow from autotrophs to $\mathrm{MH}$ plants by way of shared fungi. Since they do not exclude other scenarios, only a direct labelling of tree photosynthates would definitively assess whether mycelial links between trees and orchids allow a flow to MH plants. In this regard, the putative scenario and $\mathrm{C}$ and $\mathrm{N}$ data obtained here do not differ from those observed in temperate $\mathrm{MH}$ orchids. The existence and roles of common mycorrhizal networks have often been speculated in tropical ecosystems [58], but rigorous demonstration is still lacking: inter-plant $\mathrm{C}$ transfers are striking indirect evidence of their existence [26].

\section{Mixotrophy in tropical orchids}

In temperate regions, green plants phylogenetically related to $\mathrm{MH}$ plants recover part of their $\mathrm{C}$ from their mycorrhizal fungi, especially among orchids $[21,38,42,46]$. This photosynthetic and partially $\mathrm{MH}$ nutrition, also called mixotrophy, is considered as an adaptation to understorey conditions, with low light levels. It can thus be expected in dense tropical forests, but has not yet been demonstrated [2]. Mixotrophy entails ${ }^{13} \mathrm{C}$ and ${ }^{15} \mathrm{~N}$ natural abundances intermediate between those of fully autotrophic and MH plants $[21,41,59]$. Here, Cheirostylis montana at Doi Pee Pan Nam had ${ }^{13} \mathrm{C}$ abundance significantly differing from autotrophs and closer to that in ECM fungi and A. caudata. Since the ${ }^{13} \mathrm{C}$ content $(-27.1 \pm 1.5 \%$ o $)$ is too low for a $\mathrm{C} 4$ photosynthetic metabolism [18], mixotrophy is likely to occur. A linear two-sources mixing model [60], with mean $\delta^{13} \mathrm{C}$ values of autotrophs and $\mathrm{MH}$ plants as references, suggests that $82 \%$ of its $\mathrm{C}$ was of fungal origin (significantly different from zero based on $95 \%$ confidence intervals).

Mycorrhizal partners of Cheirostylis montana have not been investigated yet, but deserve further attention. Indeed, most research on tropical orchid mycorrhizae deals with epiphytic species, and only a few terrestrial species have been studied, using in vitro isolation techniques that revealed only rhizoctonia fungi [61]. However, several 
ECM fungi are difficult or impossible to isolate [6], and therefore molecular approaches are strongly recommended in future attempts to identify fungi of tropical terrestrial orchids. Using such approaches, tropical ecosystems may provide model systems for the examination of mixotrophy in diverse species beyond orchids.

\section{Absence of mycorrhizal specificity in Aphyllorchis spp}

The lack of mycorrhizal specificity in A. montana and A. caudata is unexpected for MH species. Such a low specificity, observed both at population and individual levels (Figure 4), is very unusual among orchids [31], but has been found in some mixotrophic Neottieae in the genera Cephalanthera and Epipactis [36,41-44]. Aphyllorchis species associated with various ECM fungi at the population, individual, root and cell levels (Figure 5), and no obligate or constant partner was identified. In contrast, C. exigua associated quite specifically with Thelephoraceae, and suggested that our design did allow detection of specificity. Moreover, rarefaction curves confirmed that for whatever sampling effort, C. exigua presented a lower diversity (Figure 7a). Since Aphyllorchis fungal communities look like ECM communities from tropical regions [46,62], they may even reflect a random sampling of available ECM fungi by orchids' roots. However, given our limited knowledge of ECM diversity in Thailand forests, we do not know whether there is over- or underrepresentation of ECM fungal taxa colonising nearby trees. Interestingly, Sclerodermataceae, which are common in Thailand dipterocarpacean forests [47], were absent in orchid roots. We thus cannot exclude some limited mycorrhizal preference in Aphyllorchis spp. An intriguing consideration is that specificity in green or MH orchids, like C. exigua (Figure 1), correlates with short roots (less than $10 \mathrm{~cm}$ in length, or even absent; Roy, personal observation), whereas nonspecific species, such as Aphyllorchis spp., have long roots (up to $50 \mathrm{~cm}$; Figure 1).

Aphyllorchis species contrast with the highly specific temperate MH Neottieae studied so far, such as Neottia nidusavis (with Sebacinales [5]) and C. austinae (with Thelephoraceae [37]). Ironically, Aphyllorchis' closest phylogenetic relative, the mixotrophic Limodorum abortivum (Figure 2), specifically associates with the Russulaceae [38]. A strong trend toward specificity is reported in nearly all $\mathrm{MH}$ plants $[1,6]$ : individuals are associated with a narrow fungal clade of fungus, and specificity results in local specialisation or even specialisation toward distinct genotypes within populations $[7,63]$. To the best of our knowledge, the only reported exceptions are (i) two taxa of AM fungi in MH African Burmannia congesta and Sciaphila ledermannii [64]; (ii) saprobic Basidiomycetes in the Caribbean MH Wullschlaegelia aphylla [17], an orchid distantly related to Neottieae; and (iii) the case of another $\mathrm{MH}$ orchid, Erythrorchis cassythoides [65]. Other tropical MH orchids are specific (for example, [14,52]). Thus, tropical $\mathrm{MH}$ orchids exhibit different specificity levels, as reported for tropical green epiphytic orchids $[66,67]$.

There are two caveats to the conclusion of non-specificity. Firstly, we do not know whether all or only some of these fungi are providing $\mathrm{C}$ : functional specificity cannot be ruled out. Nevertheless, no constant partner was identified, suggesting that several different fungi can provide $\mathrm{C}$. Secondly, $\mathrm{MH}$ nutrition is also taking place at germination and early seedling development in orchids, since seeds have very few reserves: we do not know whether seedlings exhibit fungal specificity. In Cephalanthera spp., only a subset of fungi present in adult plants are efficient at this stage [44], and some orchids change or diversify their partners over their lifespan [6]. Indeed, if seedlings also have a large host spectrum, Aphyllorchis spp. may not be limited by availability of fungal partners. They are widespread but remain rare, with loose populations (individuals are often separated by a few meters [28], Roy and Watthana, personal observations). Thus, a different specificity in early life stages cannot be excluded in Aphyllorchis, and requires further investigation. Several observations of the association during in situ germination were obtained in temperate regions, after sowing seeds in mesh bags [31], but this remains to be applied in tropical ecosystems.

\section{Why is fungal specificity low in tropical $\mathrm{MH}$ orchids?}

Interestingly, the few non-specific $\mathrm{MH}$ plants reported so far occur all in tropical ecosystems [17,64,65]. Although this may be pure coincidence, it may suggest some particular features of $\mathrm{MH}$ plants and/or fungal communities in tropical ecosystems. Specificity in biological interactions reveals variable latitudinal patterns, ranging from higher specificity in the tropics (for example, for plant endophytic fungi [68]) to similar or lower specificity (for example, for phytophageous and pollinating insects [69]). Difference between latitudes thus relates more to the functioning of each interaction. However, the raison d'être of MH specificity remains poorly understood in temperate MH species. Two non-excluding models were proposed, namely functional co-adaptation and parasitic co-evolution [70]. Functional co-adaptation states that the mechanism reversing the $\mathrm{C}$ flow (which goes from plant to fungus in common mycorrhizae [71]) requires fine plant adaptations to fungal physiology, and that specific adaptations are better than universal ones (functioning with any fungus). However, the many shifts of fungal partners during the evolution of $\mathrm{MH}$ lineages $[8,10]$ are not predicted by this model. Parasitic co-evolution assumes that $\mathrm{MH}$ plants parasitise their mycorrhizal fungus (and thus 'epiparasitise' on green plants [1]), although there is no direct evidence of detrimental effects $[39,70]$. In this case, specificity would evolve within an arms race between the 


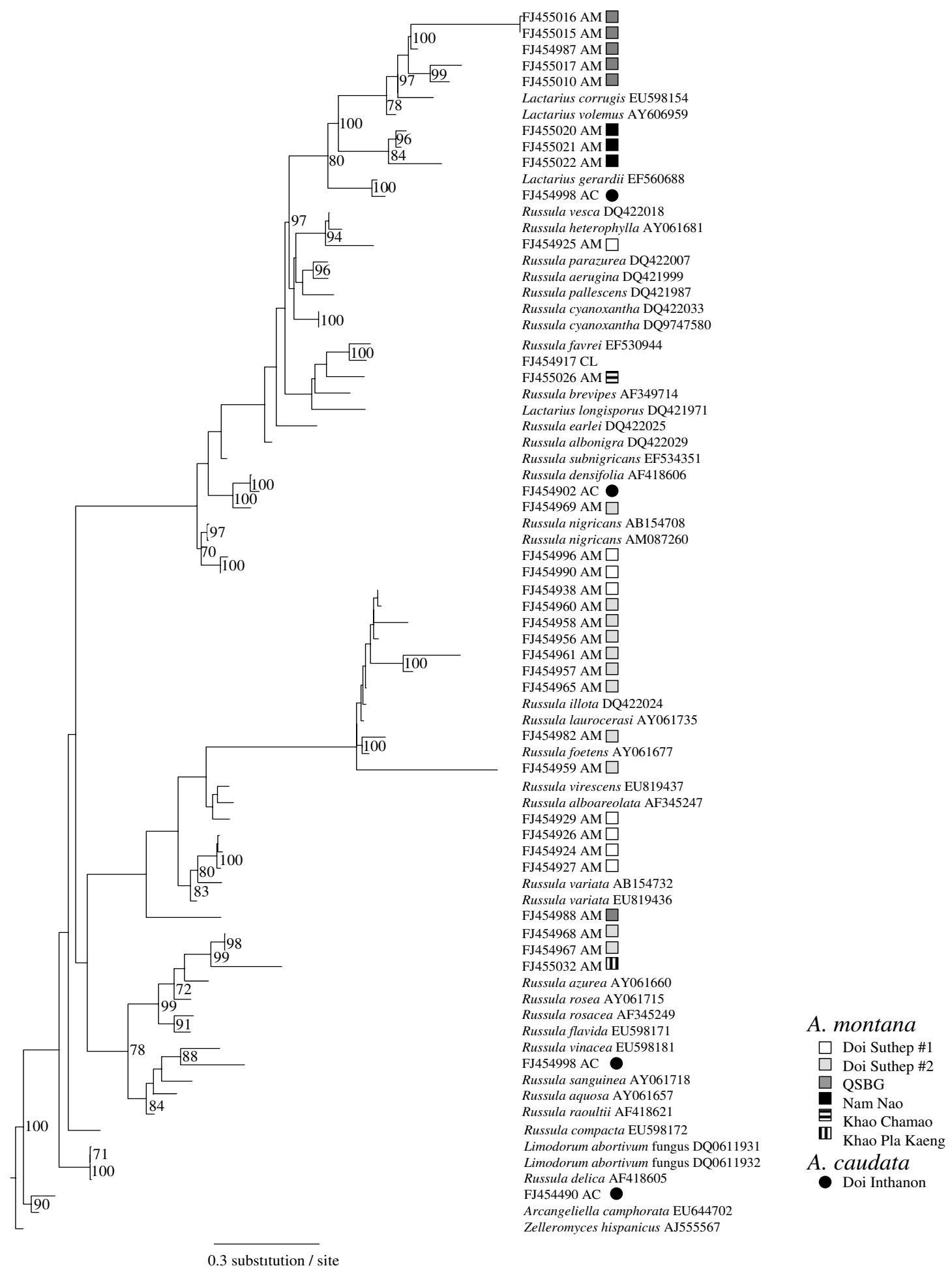

Figure 6

Over-dispersion of Russulaceae isolated from A. montana and A. caudata. Unrooted phylogenetic tree placing the Russulaceae identified from Aphyllorchis montana (AM) and A. caudata (AC). This phylogeny is based on internal transcribed spacer sequences, using maximum likelihood (general time reversible model). Numbers on nodes indicated bootstrap values above $70 \%$ (over 10,000 replicates). 
a

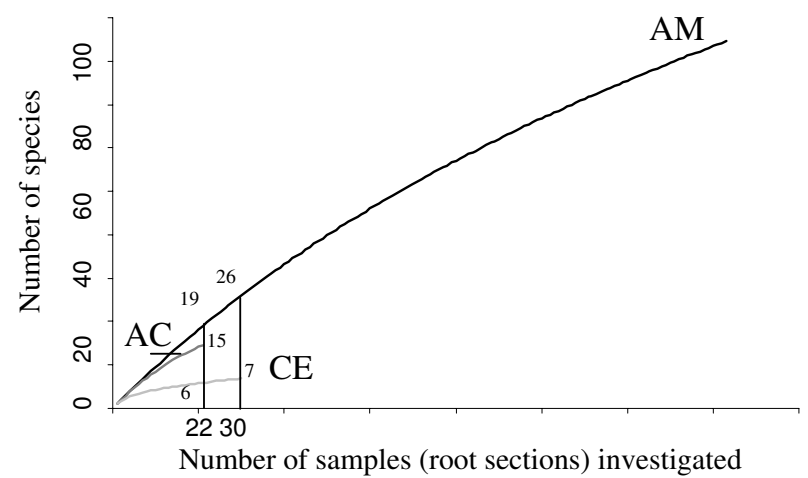

b

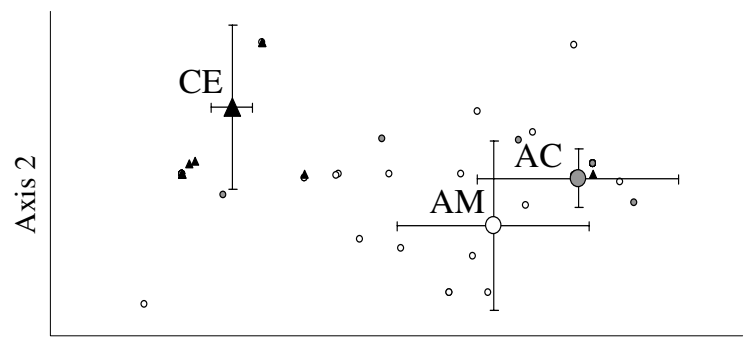

Axis 1

\section{Figure 7}

Differences between the three mycoheterotrophic orchid fungal communities. Comparison of the fungal communities found on the three orchid species (AM, A. montana, AC, A. caudata and CE, C. exigua). (a) Rarefaction curves for ectomycorrhizal fungal species. (b) Detrended component analysis of orchid individuals plotted in two dimensions, based on ectomycorrhizal fungal communities (fungal taxa grouped by families; note that most points are superimposed). White circles: $A$. montana individuals; grey circles: A. caudata; black triangles: C. exigua. Large symbols represent means for each species, with standard deviations.

fungus and the MH plant: first, epiparasitic plants can only associate with exploitable fungi that are somehow resistant to epiparasitism (non-resistant fungi may not support epiparasites and the association could not be maintained), then both partners may select for adaptations reducing the cost of this association, and such adaptations makes the association more and more specific. As a result, few co-evolved plant-fungus combinations are successful, and evidence for local adaptation in MH populations $[10]$ and co-evolution with fungi $[12,63]$ support this. Our study and a few others $[18,64,65]$ suggest that these mechanisms at least do not apply to tropical $\mathrm{MH}$ plants.

We propose a common reason to explain non-specificity in (i) any mixotrophic plants, and (ii) tropical $\mathrm{MH}$ orchids. In both cases, the $\mathrm{C}$ demand would not be very costly for the fungus. We respectively assume that (i) mixotrophic plants have limited $\mathrm{C}$ requirements, because of their photosynthesis, and (ii) due to better tree photosynthesis (higher primary production) in the tropics, tropical ECM fungi receive a greater $\mathrm{C}$ flow. In both cases, the $\mathrm{C}$ uptake would be relatively negligible, as compared with the $\mathrm{C}$ demand of $\mathrm{MH}$ plants on temperate ECM fungi. Thus, functional co-adaptation and/or parasitic co-evolution would not apply in tropical regions since avoidance mechanisms are selected only if the cost of avoidance is lower than the cost of interaction [72]. This statement remains speculative, since we know little about the $\mathrm{C}$ budget in individual mycelia, and comparative fungal physiology in tropical versus temperate regions. More studies of orchid-fungal diversity in tropical ecosystems are required to support it. Making this assumption, specific MH plants and also some specific temperate mixotrophic plants (such as Limodorum abortivum [38]) would simply go beyond a threshold in terms of $\mathrm{C}$ loss for the fungus, thus entering the co-adaptation and/or parasitic co-evolution process leading to specificity. Alternative explanations remain possible: heterogeneous environments make generalists fitter than specialists $[73,74]$. Unfortunately, we do not know the structure and spatial heterogeneity of ECM at our sampling sites, and there is even some evidence that tropical ECM communities are less diverse than temperate ones (K Nara, personal communication).

\section{Conclusion}

All Neottieae examined to date in both temperate and, now, tropical ecosystems have been found to associate with ECM fungi. In most cases, they receive $\mathrm{C}$ from ECM mycelial networks linking them to nearby trees, as shown by their isotopic content. During Neottieae evolution, specificity arose repeatedly, but unexpectedly this turns out to be unrelated to full MH nutrition; in spite of several shifts in fungal partners, some phylogenetic inertia may have occurred. The lack of specificity is encountered for a few other tropical MH plants, suggesting that $M H$ and fungal organisms from tropical ecosystems may differ functionally from their temperate analogues. This and the observation of mixotrophy in green orchids calls for more focus on mycorrhizal associations of terrestrial herbaceous plants in the tropics, to know more on the taxonomic position of their fungi and functional diversity (especially in terms of $\mathrm{C}$ flow) of their mycorrhizal association.

\section{Methods}

Model species and sampling sites

Aphyllorchis montana Rchb.f., A. caudata Rolfe ex Downie and Cephalanthera exigua Seidenf. are MH orchids (Figure 1) from South-East Asia that grow in low to high moun- 


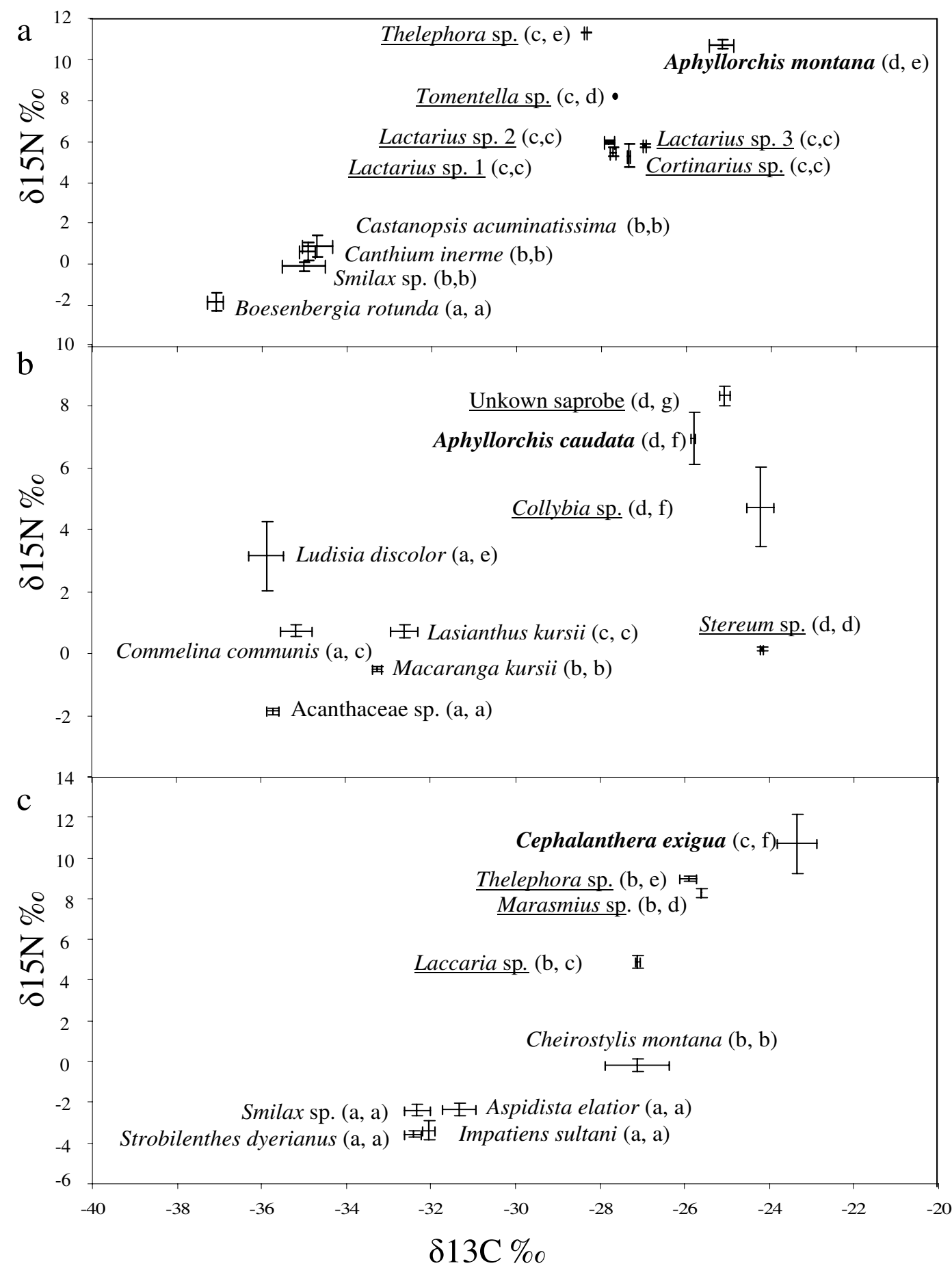

\section{Figure 8}

Isotopic signature of the three mycoheterotrophs studied and other green orchids. Carbon versus nitrogen stable isotope values (\%o) of green plants, mycoheterotrophic plants (names bold) and fungi (names underlined) at (a) Doi Suthep \#2 (including A. montana and various ectomycorrhizal (ECM) fungi), (b) Doi Suthep \#3 (including A. caudata and various saprobic fungi), (c) Doi Pee Pan Nam (including C. exigua, two ECM fungi and a saprobic Marasmius). Letters in brackets denote significant differences between species for both $\delta^{13} \mathrm{C}$ (first letter) and $\delta^{15} \mathrm{~N}$ (second letter), according to pairwise Mann-Whitney tests $(P<0.0$ l at least); bars indicate standard deviations. 

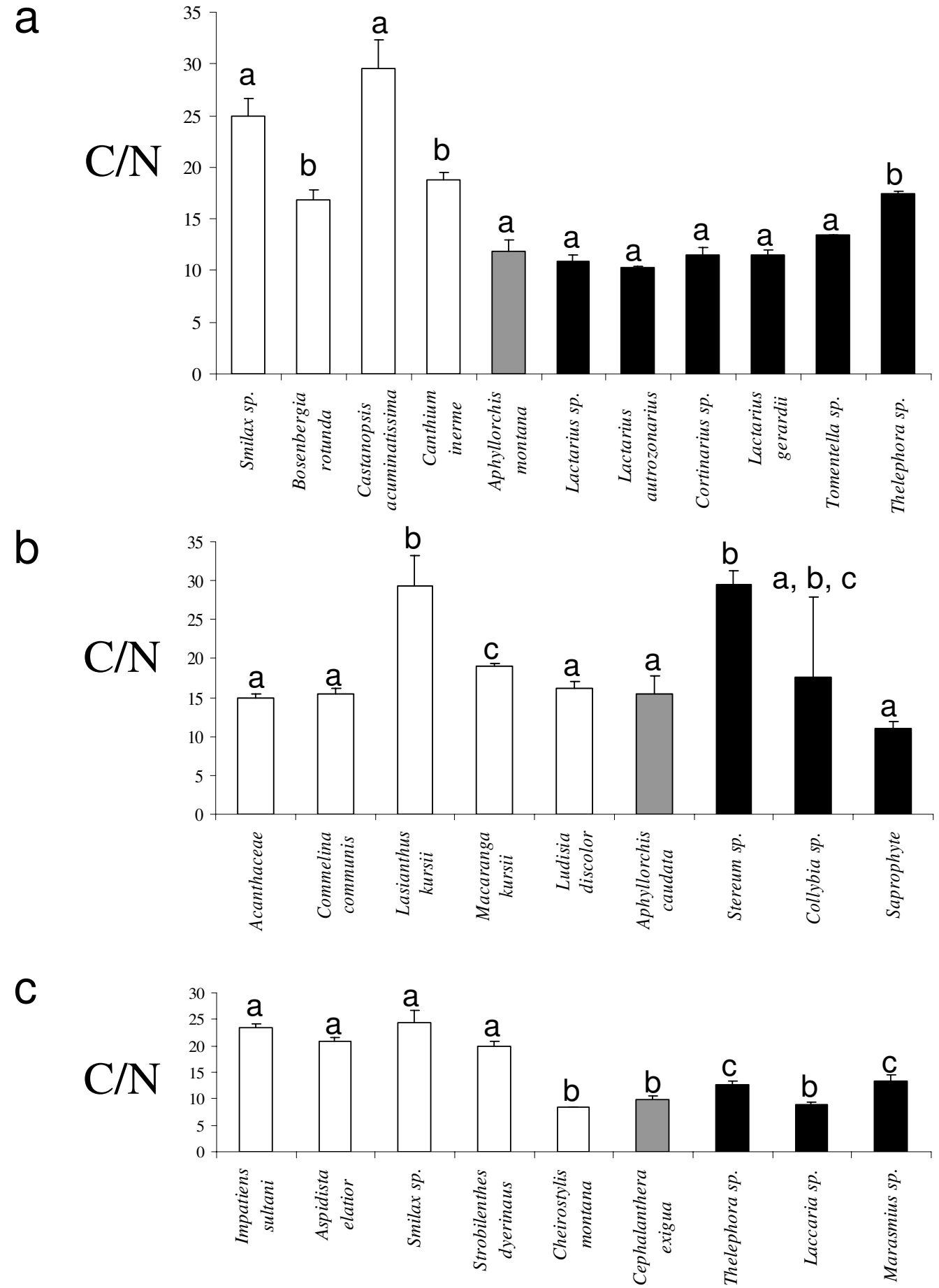

Figure 9

$\mathrm{C} / \mathrm{N}$ ratio values of the three mycoheterotrophic orchids and other green orchids $\mathrm{C} / \mathrm{N}$ ratio values of green plants, (white bars), mycoheterotrophic plants (grey bars) and fungi (black bars) from three sites: Doi Suthep \#2 ((a), including A. montana and various ectomycorrhizal (ECM) fungi), Doi Suthep \#3 ((b), including A. caudata, various saprobic fungi), Doi Pee Pan Nam ((c), including $C$. exigua, two ECM fungi and a saprobic Marasmius). Letters denote significant differences between species, according to pairwise Mann-Whitney tests $(P<0.01$ at minimum); bars indicate the standard deviation. 
tain forests [28]. C. exigua blooms during the dry season (April), whereas the two Aphyllorchis spp. bloom during the rainy season (July to August). All roots were harvested from large populations at the beginning of their flowering period in 2006 and 2007, with the authorisation of the National Council for Research of Thailand. Samples were collected from 10 different sampling sites, separated by $500 \mathrm{~m}$ to $1000 \mathrm{~km}$ in diverse parts of Thailand (NorthWest, Central and South-East) with different forest types (evergreen, pine-oak or dry dipterocarpacean forest) - see details and site names in Table 1.

\section{Sampling for molecular analysis}

We harvested three to six independent root fragments (> $3 \mathrm{~cm}$ in length) using a protocol that allows plant survival (careful approach to plant roots by digging from one side and, after sampling, refilling of the hole with the same soil without direct rhizome disturbance [8]). We discarded roots specialised in starch accumulation (often occurring in Neottieae [31]) and roots showing infections or symptoms of decay. Within $2 \mathrm{~h}$ after harvesting, the remaining roots were carefully washed with water to eliminate soil particles, surface-sterilised using a solution of sodium hypochloride $(2 \% \mathrm{v} / \mathrm{v})$ and Tween $80(5 \% \mathrm{w} / \mathrm{v})$ for $10 \mathrm{~s}$, and rinsed three times in sterile distilled water. Roots were then enveloped in paper and stored in silica gel. Next, 1 mm-long sections were sampled every centimetre on the roots, and their colonisation was checked under the microscope using the neighbouring root section ( 3 to 15 colonised samples were recovered per plant). To identify directly the fungi forming pelotons (intracellular hyphal coils produced by orchid mycorrhizal fungi), pelotons were isolated under a microscope according to Rasmussen [31] on A. montana individuals AMD6.1 and AMD7.1 from Doi Suthep \#2 (Table 1 and Additional file 2). For 10 root sections per individual, 12 pelotons were recovered and pooled per section $(2 \times 10=20$ peloton pools in all).

\section{Molecular investigations}

DNA extraction and PCR amplification of fungal ITS of ribosomal DNA were performed as in Selosse et al. [5] on root fragments and peloton pools. Whenever PCR failed, we tentatively amplified (i) the large mitochondrial ribosomal subunit gene (LrDNA) as in Roy et al. [8], and (ii) the 5' part of the 28S rDNA, using the primers LrOr and Lr5 as in Roy et al. [8]. Some PCR products with multiple bands were cloned as in Roy et al. [8], and at least five clones per individual were recovered. Before sequencing, RFLP, using EcoRI+SacI and HindIII, as in Selosse et al. [5] was investigated to avoid repetitive sequencing of the same ITS. To investigate the phylogenetic position of the investigated orchid species, we amplified (conditions in Selosse et al. [5]) and sequenced (i) the plant ITS, using the plant-specific primer ITS1P; (ii) $r b c L$ using primer
rbcL1F (5'-ATGTCACCACAAACAGAAAC-3') and rbcL 1367R (5'-CTTCCAAATTTCACAAGCAGCA-3'); and (iii) trnS-G using a primer on trnS (5'-GCCGCTTTAGTCCACTCAGC-3') and the other on trnG (5'-GAACGAATCACACTTTTACCAC-3'). These loci were also amplified in other Neottieae, such as Cephalanthera exigua, C. damasonium Druce, C. longifolia (L.) Fritsch, C. rubra (L.) Rich., Epipactis helleborine (L.) Crantz, E. muelleri Godfery, E. fageticola (C.E.Hermos.) Devillers-Tersch. \& Devillers, E. fibri Scappat. \& Robatsch, E. palustris Crantz, E. flava Seidenf., E. microphylla Sieber. ex Nyman, Neottia ovata Bluff \& Fingerh., N. nidus-avis (L.) Rich., Limodorum abortivum (L.) Sw., and Thaia saprophytica Seidenf. (Additional file 1). Tropidia curculigoides Lindl. was sequenced as an outgroup. Sequencing and sequence editing was performed as in Roy et al. [8] and corrected sequences (or consensus sequences for similar clones) were deposited in GenBank [75].

\section{Fungal identification and phylogenetic analyses}

In order to identify fungi, a BLAST search for similar fungal sequences was conducted [76] using GenBank [75]. Two phylogenetic analyses were conducted, in order to (i) study the phylogenetic position of Aphyllorchis spp. using a concatenation of ITS, $r b c L$ and $t r n S-G$ sequences, and (ii) to refine the phylogenetic positions of the many Russulaceae found in this study using ITS sequences (alignment and analysis were not possible for Thelephoraceae, because of too much variation in their ITS). Sequences of Neottieae and Russulaceae available in GenBank were downloaded and aligned together with ours using ClustalW [77], and then corrected by eye. Considering the high number of species of Russulaceae in GenBank, we used only species recorded from Thailand and species recovered when using BLAST for our sequences; the Russulaceae tree was not rooted. For Neottieae, Tropidia polystachya, Nervilia shinensis and Vanilla planifolia were chosen as outgroups. The phylogeny was computed by maximum likelihood with PhyML v2.4.4 [78]. For this analysis, a general time-reversible (GTR) model of DNA substitution was used $[79,80]$, involving unequal base frequencies and six types of substitution. This model of DNA substitution was chosen using a series of hierarchical likelihood-ratio tests in Modeltest 3.7 [81]. Base frequencies were estimated, and 10,000 bootstrap replicates were performed. Phylogenetic trees were visualised using Figtree 1.1.2 [82].

\section{Isotopic sampling and analysis}

Sampling for isotopic studies was conducted at three different sites (Doi Suthep \#2, Doi Suthep \#3 and Doi Pee Pan Nam; Table 1). At each site, we harvested $n=5$ samples for aerial parts of $\mathrm{MH}$ orchids, leaves of four autotrophic species, and fruitbodies of up to six basidiomycetes species fruiting at sampling time (prioritising 
ECM species). All leaves were collected in close vicinity, at the same apparent light level and the same distance from the ground (less than $0.5 \mathrm{~m}$ ) as orchids. When available, other terrestrial green orchids were collected (Ludisia discolor at Doi Suthep \#3 and Cheirostylis montana at Doi Pee Pan Nam). Samples were dried at $65^{\circ} \mathrm{C}$ for $72 \mathrm{~h}$ and handled as in Tedersoo et al. [21] to measure total N, C/N ratio and abundances of ${ }^{13} \mathrm{C}$ and ${ }^{15} \mathrm{~N}$. Isotope abundances are expressed in $\delta^{13} \mathrm{C}$ and $\delta^{15} \mathrm{~N}$ values in parts per thousand relative to international standards V-PDB and atmospheric $\mathrm{N}_{2}: \delta^{13} \mathrm{C}$ or $\delta^{15} \mathrm{~N}=\left(\mathrm{R}_{\text {sample }} / \mathrm{R}_{\text {standard }}-1\right) \times 1000$ $(\% 0)$, where $\mathrm{R}$ is the molar ratio, that is, ${ }^{13} \mathrm{C} /{ }^{12} \mathrm{C}$ or ${ }^{15} \mathrm{~N} /$ ${ }^{14} \mathrm{~N}$. The standard deviation of the replicated standard samples $(n=13)$ was $0.031 \%$ or ${ }^{13} \mathrm{C}$ and $0.237 \%$ ofor ${ }^{15} \mathrm{~N}$. Total $\mathrm{N}, \mathrm{C} / \mathrm{N}$ ratio, $\delta^{13} \mathrm{C}$ and $\delta^{15} \mathrm{~N}$ values were compared independently between species at each site by pairwise Mann-Whitney tests using Minitab ${ }^{\text {TM }}$. Thus, groups of species were delimited for each variable and the KruskalWallis test was performed, using these groups as a factor in order to study the validity of these groups more precisely.

\section{Fungal community analysis}

To infer species from ITS sequences, we applied a threshold of $97.0 \%$ sequence identity over the whole ITS region; although there is no universally applicable threshold [83], this is in agreement with our previous studies $[8,21]$. Sequences were aligned using Bioedit and a similarity matrix was calculated. The frequency $\left(\mathrm{p}_{\mathrm{i}}\right)$ of each putative ECM species among individuals and within populations was calculated to establish a Shannon diversity index and a Simpson diversity index. Indices were compared between individuals by the pairwise Mann-Whitney test. To account for our variable sampling effort among orchid species, rarefaction curves were simulated 5,000 times using analytic rarefaction 1.3 [84] on two datasets: one pooling all populations for each species, and the other separating each population and calculating a mean value for each species. For a more qualitative analysis, fungal communities at the individual level were compared within and between species by building similarity matrixes with Primer 5.2.9 [85] using the Bray-Curtis similarity index. Two matrixes were computed by grouping fungal species into families (because no species or sequence was common between orchid populations or species, see below). DCA was performed with these matrixes, using population, forest type, geographical origin and species as factors.

\section{Abbreviations}

AC: Aphyllorchis caudata; AM: Aphyllorchis montana; CE: Cephalanthera exigua; ECM: ectomycorrhiza or ectomycorrhizal; DCA: detrended component analysis; GTR: general time reversible (model); ITS: internal transcribed spacer of the ribosomal DNA; MH: mycoheterotroph.

\section{Authors' contributions}

This article is part of MR's PhD thesis. M-AS and SV designed the research; SW and MR performed the sampling; MR and AS performed the molecular research; MR, M-AS and FR analysed the data; MR and M-AS wrote the paper. All authors have read and approved the final manuscript.

\section{Additional material}

\section{Additional file 1}

Table S1. Origin and accession numbers of orchids collected for the Neottieae phylogeny. Bold numbers indicate the sequences obtained in this study, the others were retrieved from GenBank.

Click here for file

[http://www.biomedcentral.com/content/supplementary/17417007-7-51-S1.xls]

\section{Additional file 2}

Table S2. Fungi identified from A. montana, A. caudata and C. exigua mycorrhizae. Putative species were delineated on a 97\% internal transcribed spacer similarity threshold; whenever several species belong to the same taxon, their name includes a number to distinguish them, e.g. Russulaceae sp. \#3. Putative ecologies: ECM, ectomycorrhizal fungus; E: endophyte (sensu Julou et al. [41]); R: rhizoctonia; S: saprobe. ITS: Internal transcribed spacer; 28S: large ribosomal DNA subunit (28S); LrDNA: mitochondrial ribosomal DNA. Small letters refer to the DNA source used for identification, and upper numbers to the number of identical sequences retrieved from the same individual: $d$, direct PCR from root DNA; $c$, cloned PCR product from root DNA, $r$, inferred from RFLP profile; $p$, PCR from peloton DNA.

Click here for file

[http://www.biomedcentral.com/content/supplementary/17417007-7-51-S2.xls]

\section{Acknowledgements}

The authors warmly thank C Debain, M Hossaert, M-P Dubois, A Meekiijjaroenroj and $P$ Feldmann for help in launching this research programme, as well as C Shtultz and three anonymous referees for helpful comments on this article and David Marsh for editing the article. We thank the Queen Sirikit Botanical Garden and particularly Dr W Nanakorn for supporting this project, K Srimuang, P Panyachan and P-H Fabre for their help during sampling. Molecular data used in this work were produced through molecular genetic analysis technical facilities of the 'Service des Marqueurs Génétiques en Ecologie' at the 'Centre d'Ecologie Fonctionnelle et Evolutive' and of the IFRII 9 'Montpellier Environnement Biodiversité'. M-AS is funded by the Centre National de la Recherche Scientifique and the Société Française d'Orchidophilie.

\section{References}

I. Leake JR: Myco-heterotroph/epiparasitic plant interactions with ectomycorrhizal and arbuscular mycorrhizal fungi. Curr Opin Plant Biol 2004, 7:422-428.

2. Selosse MA, Roy M: Green plants that feed on fungi: facts and questions about mixotrophy. Trends Plant Sci 2009, I4(2):64-70.

3. Smith SE, Read DJ: Mycorrhizal symbiosis 3rd edition. London, UK: Academic Press; 2008.

4. Leake JR: The biology of myco-heterotrophic (Saprophytic) Plants. New Phytol 1994, 127:171-216. 
5. Selosse MA, Weiss M, Jany JL, Tillier A: Communities and populations of sebacinoid basidiomycetes associated with the achlorophyllous orchid Neottia nidus-avis (L.) LCM Rich. and neighbouring tree ectomycorrhizae. Mol Ecol 2002, I I:1831-1844

6. Taylor DL, Bruns TD, Leake JR, Read DJ: Mycorrhizal specificity and function in myco-heterotrophic plants. In Mycorrhizal Ecology Volume 157. Edited by: Sanders I, van der Hijden M. Berlin, Germany: Springer; 2002:375-4I3.

7. Taylor DL, Bruns TD, Szaro TM, Hodges SA: Divergence in mycorrhizal specialization within Hexalectris spicata (Orchidaceae), a nonphotosynthetic desert orchid. Am J Bot 2003, 90: I I68-1179.

8. Roy M, Yagame T, Yamato M, Iwase K, Heinz C, Faccio A, Bonfante P, Selosse MA: Ectomycorrhizal Inocybe species associate with the mycoheterotrophic orchid Epipogium aphyllum but not with its asexual propagules. Ann Bot 2009. published online.

9. Dearnaley JDW: Further advances in orchid mycorrhizal research. Mycorrhiza 2007, 17:475-486.

10. Bidartondo MI: The evolutionary ecology of myco-heterotrophy. New Phytol 2005, 167:335-352.

II. Bidartondo MI, Redecker D, Hijri I, Wiemken A, Bruns TD, Dominguez L, Sersic A, Leake JR, Read DJ: Epiparasitic plants specialized on arbuscular mycorrhizal fungi. Nature 2002 419:389-392.

12. Merckx V, Chatrou LW, Lemaire B, Sainge MN, Huysmans S, Smets EF: Diversification of myco-heterotrophic angiosperms: evidence from Burmanniaceae. BMC Evol Biol 2008, 8: I-16.

13. Sainge MN, Franke T: A new species of Afrothismia (Burmanniaceae) from Cameroon. Nord J Bot 2004, 23:299-303.

14. Yamato M, Yagame T, Suzuki A, Iwase K: Isolation and identification of mycorrhizal fungi associating with an achlorophyllous plant, Epipogium roseum (Orchidaceae). Mycoscience 2005, 46:73-77.

15. Ogura-Tsujita $Y$, Yukawa $\mathrm{T}$ : High mycorrhizal specificity in a widespread mycoheterotrophic plant, Eulophia zollingeri (Orchidaceae). Am J Bot 2008, 95:93-97.

16. Ogura-Tsujita Y, Gebauer G, Hashimoto T, Umata H, Yukawa T: Evidence for novel and specialized mycorrhizal parasitism: the orchid Gastrodia confusa gains carbon from saprotrophic Mycena. Proc R Soc Lond B Biol Sci 2009, 276:76I-767.

17. Martos F, Dulormne M, Pailler T, Bonfante P, Faccio A, Fournel J, Dubois MP, Selosse MA: Challenging ecological rules drawn from temperate regions: some tropical achlorophyllous orchids receive carbon from saprobic fungi. New Phytol 2009 in press.

18. Dawson TE, Mambelli S, Plamboeck AH, Templer PH, Tu KP: Stable isotopes in plant ecology. Ann Rev Ecol Syst 2002, 33:507-559.

19. Post DM: Using stable isotopes to estimate trophic position: models, methods, and assumptions. Ecology 2002, 83:703-7/8.

20. Trudell SA, Rygiewicz PT, Edmonds RL: Nitrogen and carbon stable isotope abundances support the myco-heterotrophic nature and host-specificity of certain achlorophyllous plants. New Phytol 2003, 160:39I-40I.

21. Tedersoo L, Pellet P, Koljalg U, Selosse MA: Parallel evolutionary paths to mycoheterotrophy in understorey Ericaceae and Orchidaceae: ecological evidence for mixotrophy in Pyroleae. Oecologia 2007, 1 5 1:206-217.

22. Mayor JR, A SE, Henkel TW: Elucidating the nutritional dynamics of fungi using stable isotopes. Ecol Lett 2009, 12:171-183.

23. Boström B, Comstedt D, Ekblad A: Isotope fractionation and 13 $C$ enrichment in soil profiles during the decomposition of soil organic matter. Oecologia 2007, 153:89-98.

24. Zimmer K, Meyer C, Gebauer G: The ectomycorrhizal specialist orchid Corallorhiza trifida is a partial myco-heterotroph. New Phytol 2008, 178:395-400.

25. McKendrick SL, Leake JR, Taylor DL, Read DJ: Symbiotic germination and development of the myco-heterotrophic orchid Neottia nidus-avis in nature and its requirement for locally distributed Sebacina spp. New Phytol 2002, 154:233-247.

26. Selosse MA, Richard F, He XH, Simard SW: Mycorrhizal networks: des liaisons dangereuses? Trends Ecol Evol 2006, 21:621-628.

27. Roberts DL, Solow AR: The effect of the convention on international trade in endangered species on scientific collections. Proc R Soc Lond B Biol Sci 2008, 275:987-989.
28. Seidenfaden G: Orchid genera in Thailand VI: Neottioideae Lindl Dansk Botanisk Forening; 1978

29. Suarez JP, Weiss M, Abele A, Garnica S, Oberwinkler F, Kottke I: Diverse tulasnelloid fungi form mycorrhizas with epiphytic orchids in an Andean cloud forest. Mycol Res 2006, I 1 0: 1257-1270.

30. Otero JT, Flanagan NS, Herre EA, Ackerman JD, Bayman P: Widespread mycorrhizal specificity correlates to mycorrhizal function in the neotropical, epiphytic orchid lonopsis utricularioides (Orchidaceae). Am J Bot 2007, 94: 1944-1950.

31. Rasmussen HN: Terrestrial orchids - from seed to mycotrophic plant Cambridge, UK: Cambridge University Press; 1995.

32. Alexander IJ, Lee SS: Mycorrhizas and ecosystem processes in tropical rain forest: implications for diversity. In Biotic Interactions in the Tropics: Their Role in the Maintenance of Species Diversity Cambridge, UK: Cambridge University Press; 2005:165-203.

33. Weiss M, Selosse MA, Rexer KH, Urban A, Oberwinkler F: Sebacinales: a hitherto overlooked cosm of heterobasidiomycetes with a broad mycorrhizal potential. Mycol Res 2004, 108:1003-1010

34. Athipunyakom P: Mycorrhizal fungi of terrestrial orchids: isolation, identification and symbiotic germination. In $P h D$ thesis Thailand: Kasetsart University; 2004.

35. Pridgeon A, Cribb PJ, Chase MM: Genera orchidacearum: Epidendroidae Volume 4. Oxford, UK: Oxford University Press; 2008.

36. Abadie JC, Puttsepp U, Gebauer G, Faccio A, Bonfante P, Selosse MA Cephalanthera longifolia (Neottieae, Orchidaceae) is mixotrophic: a comparative study between green and nonphotosynthetic individuals. Can J Bot 2006, 84: |462-1477.

37. Taylor DL, Bruns TD: Independent, specialized invasions of ectomycorrhizal mutualism by two nonphotosynthetic orchids. Proc Natl Acad Sci USA 1997, 94:45 I0-4515.

38. Girlanda M, Selosse MA, Cafasso D, Brilli F, Delfine S, Fabbian R, Ghignone S, Pinelli P, Segreto R, Loreto F, Cozzolino S, Perotto S: Inefficient photosynthesis in the Mediterranean orchid Limodorum abortivum is mirrored by specific association to ectomycorrhizal Russulaceae. Mol Ecol 2006, 15:49|-504.

39. Selosse MA, Bauer R, Moyersoen B: Basal hymenomycetes belonging to the Sebacinaceae are ectomycorrhizal on temperate deciduous trees. New Phytol 2002, I55:183-195.

40. Dressler RL: The Neottieae in orchid classification. Lindleyana 1990, 5:102-109.

4I. Julou T, Burghardt B, Gebauer G, Berveiller D, Damesin C, Selosse MA: Mixotrophy in orchids: insights from a comparative study of green individuals and nonphotosynthetic individuals of Cephalanthera damasonium. New Phytol 2005, 166:639-653.

42. Bidartondo MI, Burghardt B, Gebauer G, Bruns TD, Read DJ: Changing partners in the dark: isotopic and molecular evidence of ectomycorrhizal liaisons between forest orchids and trees. Proc R S Lond B Biol Sci 2004, 27 I: I 799-I806.

43. Selosse MA, Faccio A, Scappaticci G, Bonfante P: Chlorophyllous and achlorophyllous specimens of Epipactis microphylla (Neottieae, Orchidaceae) are associated with ectomycorrhizal septomycetes, including truffles. Microb Ecol 2004, 47:416-426

44. Bidartondo MI, Read DJ: Fungal specificity bottlenecks during orchid germination and development. Mol Ecol 2008, 17:3707-3716.

45. Lee SL, Alexander IJ, Watling R: Ectomycorrhizas and putative ectomycorrhizal fungi of Shorea leprosula Miq. (Dipterocarpaceae). Mycorrhiza 1997, 7:63-8I.

46. Riviere T, Diedhiou AG, Diabate M, Senthilarasu G, Natarajan K, Verbeken A, Buyck B, Dreyfus B, Bena G, Ba AM: Genetic diversity of ectomycorrhizal Basidiomycetes from African and Indian tropical rain forests. Mycorrhiza 2007, 17:415-428.

47. Yuwa-Amornpitak T, Vichitsoothonkul T, Tanticharoen M, Cheevadhanarak S, Ratchadawong S: Diversity of Ectomycorrhizal fungi on Dipterocarpaceae in Thailand. J Biol Sci 2006, 6: 1059- 1064.

48. Moyersoen B: Pakaraimaea dipterocarpacea is ectomycorrhizal, indicating an ancient Gondwanaland origin for the ectomycorrhizal habit in Dipterocarpaceae. New Phytol 2006, I 72:753-762.

49. Ouanphanivanh N, Merenyi Z, Orczan AK, Bratek Z, Szigeti Z, Illyes $Z$ : Could orchids indicate truffle habitats? Mycorrhizal association between orchids and truffles. Acta Biol Szeged 2008, 52:229-232. 
50. Yamato M, Iwase K: Introduction of asymbiotically propagated seedlings of Cephalanthera falcata (Orchidaceae) into natural habitat and investigation of colonized mycorrhizal fungi. Ecol Res 2008, 23:329-337.

51. Umata H: In vitro germination of Erythrorchis ochobiensis (Orchidaceae) in the presence of Lyophyllum shimeji, an ectomycorrhizal fungus. Mycoscience 1997, 38:355-357.

52. Yagame T, Yamato M, Suzuki A, Iwase K: Ceratobasidiaceae mycorrhizal fungi isolated from nonphotosynthetic orchid Chamaegastrodia sikokiana. Mycorrhiza 2008, I8:97-I0I.

53. Terashita T, Chuman S: Fungi inhabiting wild orchids in Japan (IV). Armillaria tabescens, a new symbiont of Galeola septentrionalis. Trans Mycol Soc Jpn 1987, 28: |45-I54.

54. Umata H: Seed germination of Galeola altissima, an achlorophyllous orchid, with aphyllophorales fungi. Mycoscience 1995, 36:369-372.

55. Umata $\mathrm{H}$ : A new biological function of Shiitake mushroom, Lentinula elodes, in a mycoheterotrophic orchid, Erythrorchis ochobiensis. Mycoscience 1998, 39:85-88.

56. McKendrick SL, Leake JR, Read DJ: Symbiotic germination and development of myco-heterotrophic plants in nature: transfer of carbon from ectomycorrhizal Salix repens and Betula pendula to the orchid Corallorhiza trifida through shared hyphal connections. New Phytol 2000, I45:539-548.

57. Zeller B, Brechet C, Maurice JP, Le Tacon F: C-I3 and N-I5 isotopic fractionation in trees, soils and fungi in a natural forest stand and a Norway spruce plantation. Ann Forest Sci 2007, 64:419-429.

58. McGuire KL: Common ectomycorrhizal networks may maintain monodominance in a tropical rain forest. Ecology 2007, 88:567-574.

59. Gebauer G, Meyer M: N-I5 and C-I3 natural abundance of autotrophic and mycoheterotrophic orchids provides insight into nitrogen and carbon gain from fungal association. New Phytol 2003, I 60:209-223.

60. Phillips DL, Gregg JW: Uncertainty in source partitioning using stable isotopes. Oecologia 200I, I 28:304

6I. Bougoure JJ, Bougoure DS, Cairney JWG, Dearnaley JDW: ITSRFLP and sequence analysis of endophytes from Acianthus, Caladenia and Pterostylis (Orchidaceae) in southeastern Queensland. Mycol Res 2005, 109:452-460.

62. Tedersoo L, Suvi T, Beaver K, Koljalg U: Ectomycorrhizal fungi of the Seychelles: diversity patterns and host shifts from the native Vateriopsis seychellarum (Dipterocarpaceae) and Intsia bijuga (Caesalpiniaceae) to the introduced Eucalyptus robusta (Myrtaceae), but not Pinus caribea (Pinaceae). New Phytol 2007, I 75:32I-333.

63. Taylor DL, Bruns TD, Hodges SA: Evidence for mycorrhizal races in a cheating orchid. Proc $R$ Soc Lond B Biol Sci 2004, 27 I:35-43.

64. Franke T, Beenken L, Doring M, Kocyan A, Agerer R: Arbuscular mycorrhizal fungi of the Glomus-group A lineage (Glomerales; Glomeromycota) detected in myco-heterotrophic plants from tropical Africa. Mycol Prog 2006, 5:24-3I.

65. Dearnaley JDW, Le Brocque AF: Endophytic fungi associated with Australian orchids. Australas Plant Conserv 2006, I 5:7-9.

66. Otero JT, Ackerman JD, Bayman P: Diversity and host specificity of endophytic Rhizoctonia-like fungi from tropical orchids. Am J Bot 2002, 89: $1852-1858$

67. Suarez JP, Weiss M, Abele A, Oberwinkler F, Kottke I: Members of Sebacinales subgroup B form mycorrhizae with epiphytic orchids in a neotropical mountain rain forest. Mycol Prog 2008, 7:75-85.

68. Arnold AE, Henk DA, Eells RL, Lutzoni F, Vilgalys R: Diversity and phylogenetic affinities of foliar fungal endophytes in loblolly pine inferred by culturing and environmental PCR. Mycologia 2007, 99: 185-206.

69. Novotny V, Basset Y, Miller SE, Weiblen GD, Bremer B, Cizek L, Drozd $P$ : Low host specificity of herbivorous insects in a tropical forest. Nature 2002, 416:84|-844.

70. Bruns TD, Bidartondo MI, Taylor DL: Host specificity in ectomycorrhizal communities: What do the exceptions tell us? Integr Comp Biol 2002, 42:352-359.

7I. Cameron DD, Johnson I, Read DJ, Leake JR: Giving and receiving: measuring the carbon cost of mycorrhizas in the green orchid, Goodyera repens. New Phytol 2008, I80:176-I84.
72. Bronstein JL: The exploitation of mutualisms. Ecol Lett 200I, 4:277-287.

73. Ronce $O$, Kirkpatrick $M$ : When sources become sinks: migrational meltdown in heterogeneous habitats. Evolution 200I, 55:|520-|53|.

74. Lanchier N, Neuhauser C: A spatially explicit model for competition among specialists and generalists in a heterogeneous environment. Ann Appl Probab 2006, I 6: I385-1410.

75. National Center for Biotechnology Information [http:// www.ncbi.nlm.nih.gov]

76. Altschul SF, Madden TL, Schaffer AA, Zhang JH, Zhang Z, Miller W, Lipman DJ: Gapped BLAST and PSI-BLAST: a new generation of protein database search programs. Nucleic Acids Res 1997, 25:3389-3402.

77. Thompson JD, Higgins DG, Gibson TJ: CLUSTAL W: improving the sensitivity of progressive multiple sequence alignment through sequence weighting, position-specific gap penalties and weight matrix choice. Nucleic Acids Res 1994, 22:4673-4680.

78. Guindon S, Gascuel O: A simple, fast, and accurate algorithm to estimate large phylogenies by maximum likelihood. Syst Biol 2003, 52:696-704.

79. Lanave C, Preparata G, Saccone C, Serio G: A new method for calculating evolutionary substitution rates. I Mol Evol 1984, 20:86-93.

80. Rodriguez FJ, Olivier JL, Marin A, Medina JR: The general stochastic model of DNA substitution. J Theor Biol 1990, I 42:485-50 I.

8I. Posada D, Crandall KA: MODELTEST: testing the model of DNA substitution. Bioinformatics 1998, |4:817-8|8.

82. Figtree I.I.2 [http://tree.bio.ed.ac.uk/]

83. Nillsson RH, Kristiansson E, Ryberg M, Hallenberg $N$, Larsson kH: ITS variability in the Kingdom Fungi as expressed in the international sequence databases and its implications for molecular species identification. Evol Bioinform Online 2008, 4:193-201.

84. Holland SM: Analytic Rarefaction Version I.3. 2008 [http:// www.uga.edu/strata/software/]

85. Clarke KR, Gorley RN: Primer v5.2.9: User Manual: Tutorial, Primer-E. Plymouth UK 200I.
Publish with Biomed Central and every scientist can read your work free of charge

"BioMed Central will be the most significant development for disseminating the results of biomedical research in our lifetime. "

Sir Paul Nurse, Cancer Research UK

Your research papers will be:

- available free of charge to the entire biomedical community

- peer reviewed and published immediately upon acceptance

- cited in PubMed and archived on PubMed Central

- yours - you keep the copyright
BioMedcentral 